$1-1-1957$

\title{
Population change in West Virginia, 1900-1955: population estimates, natural increase, and net migration for the counties
}

Leonard Marion Sizer

Follow this and additional works at: https://researchrepository.wvu.edu/ wv_agricultural_and_forestry_experiment_station_bulletins

\section{Digital Commons Citation}

Sizer, Leonard Marion, "Population change in West Virginia, 1900-1955 : population estimates, natural increase, and net migration for the counties" (1957). West Virginia Agricultural and Forestry Experiment Station Bulletins. 401.

https://researchrepository.wvu.edu/wv_agricultural_and_forestry_experiment_station_bulletins/386 @ WVU. It has been accepted for inclusion in West Virginia Agricultural and Forestry Experiment Station Bulletins by an authorized administrator of

The Research Repository @ WVU. For more information, please contact ian.harmon@mail.wvu.edu. 


\section{Population Change in}

\section{West Virginia, $1900-1955--$}

Population Estimates,

Natural Increase, and

Net Migration for the Counties 


\section{TIE AITIIOR}

Leonard 11. Sizer is Issistant Rural Sociologist in the $\mathbb{N}$ cst Virginia I niversity Igricultural Experiment Station and Assistant l'rofessor of Rural Sociology in the College of Igriculture, Forestry, and Ilone Fcononics.

WEST VIRGINIA UNIVERSITY AGRICULTURAL EXPERIMENT STATION COLLEGE OF AGRICULTUAE, FORESTRY, AND HOME ECONOMICS H. R. VARNEY, DIRECTOR MORGANTOWN 


\section{Population Change in}

\section{West Virginia, 1900-1955--}

\section{Population Estimates, Natural Increase, and Net Migration for the Counties}

Leonard M. Sizer

West Virginia has recorded gains in population with each census from 1900 to 1950, though the rate of gain has decreased each decade, as is indicated in Table 1.

Table 1. Papulation of West Virginia, 1900-1950, and Percentage of Change from Previous Decade.*

\begin{tabular}{l|c|c}
\hline Year & Papulation & $\begin{array}{c}\text { Percentage } \\
\text { af change }\end{array}$ \\
\hline 1900 & 958,800 & \\
1910 & $1,221,119$ & 27.4 \\
1920 & $1,413,701$ & 19.9 \\
1930 & $1,729,205$ & 18.1 \\
1940 & $1,901,974$ & 10.0 \\
1950 & $2,005,552$ & 5.4 \\
\hline
\end{tabular}

\footnotetext{
-Uniled Stales Census of Population 1950, Vol. 1, Chapler 1, Tables 6 \& 7.
}

During the five-year period since 1950, information' released periodically by the Census Bureau indicates that West Virginia's population, as a whole, is declining. Previous census returns indicated that many

\footnotetext{
'United States Bureau of the Census, Curront Populalion Reports, Populalion Estlmatos, P-25, No. 125, November 8, 1956; No. 129, Jonuary 20,1958; No.145, October 19, 1956.
} 


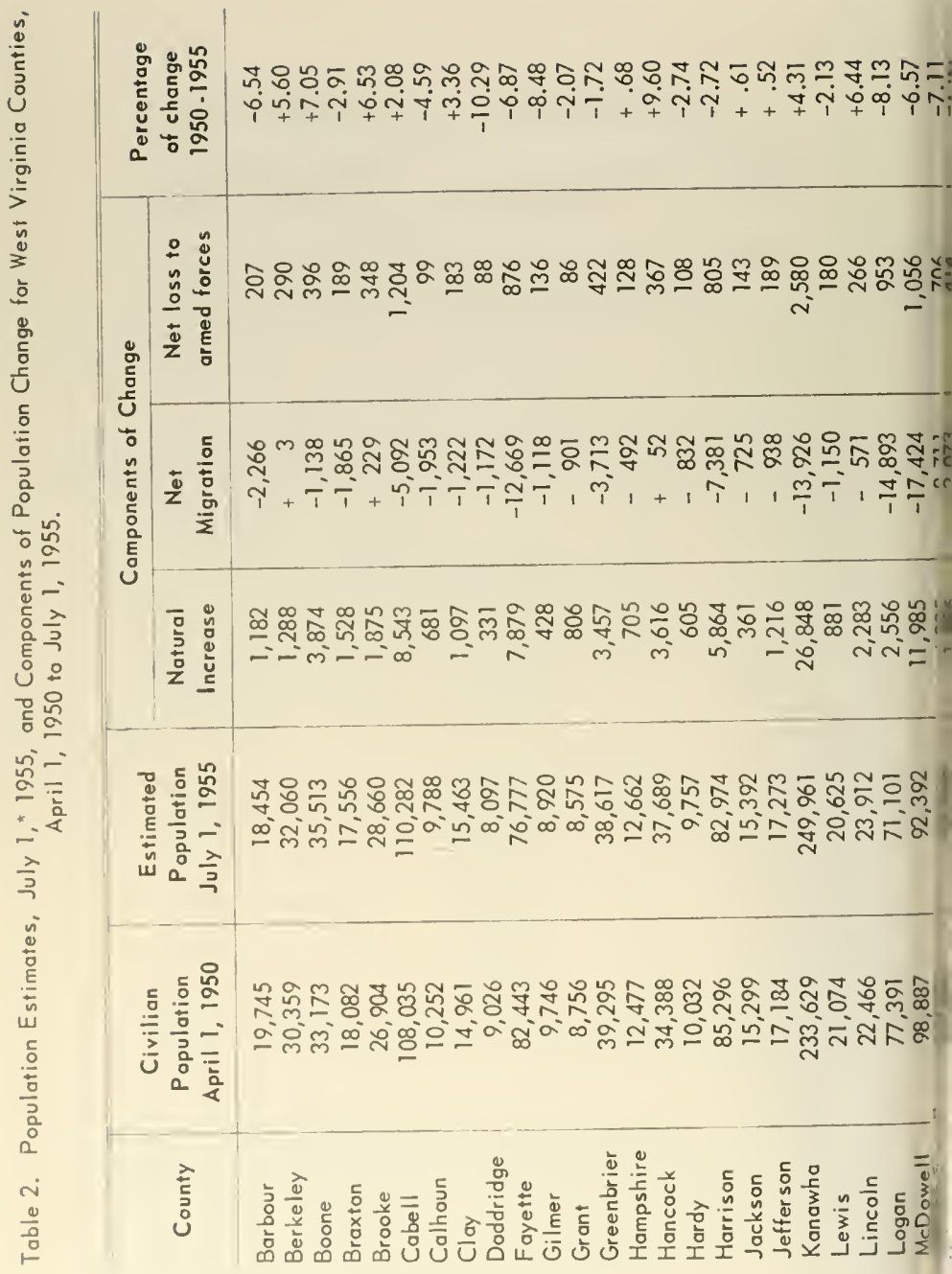




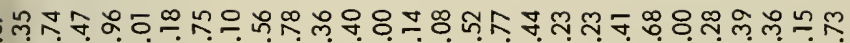

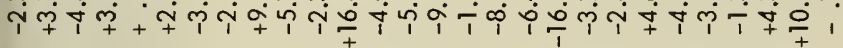

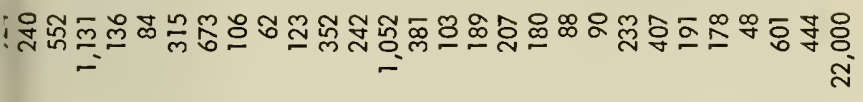

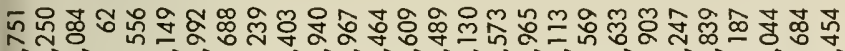

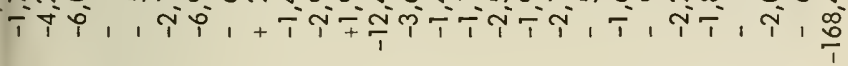

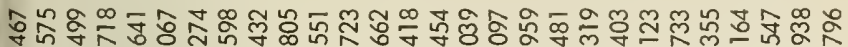
$=0 \rightarrow$ hín

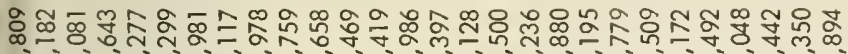

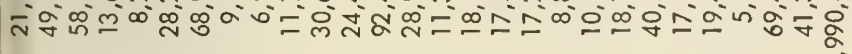

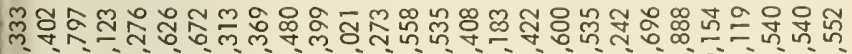

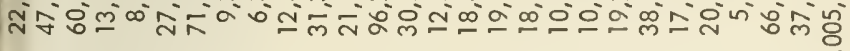

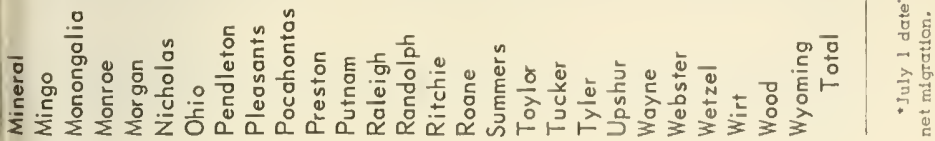


rural areas of the State have shown smaller populations with each successive census since 1900, even though the State as a whole was increasing in population.

The interplay of forces which has affected West Virginia's farm population has been concisely stated by Armentrout and Johnson as follows :

\begin{abstract}
"With the exception of the Shenandoah River Valley, The South Branch Valley, the Greenbrier Valley, and the highest plateau section north of the Greenbrier Valley, practically all of the state has had an agricultural development more or less incidental to the development of the Jumber, oil, gas, and coal industries. While major improvements were being made in the agriculture of the nation from 1880 to 1920, the agriculture in much of West Virginia was largely in a state of arrested development. The influx of populations caused by the lumber, oil and gas industries and the subsequent decline in these industries has tended to leave a larger population dependent upon agriculture than otherwise might have been the case if the land had been settled originally only for agricultural purposes. Land has been devoted to agricultural uses even where the probable income was small, because the income from lumber, oil and gas made up the difference. With a relatively small income remaining from these sources today, the occupants of the land in many sections are forced to get along on the limited income possible from agriculture alone. This has led to land uses not entirely consistent with conservation of soil or with good timber or pasture management. There is a tremendous pressure of population on the land, and low-income farmers abound.'
\end{abstract}

The situation described, together with developments within the coal industry, a drop in coal consumption, and mechanization of mining, have caused a lessening in employment opportunities within the State, resulting in a drop in the total population.

Since the 1920 census, Fest V'irginia has depended upon an excess of births over deaths for its population increase, while, at the same time, witnessing a net out-migration. ${ }^{3}$ Only recently has this stream of outmigration exceeded the total natural increase for the State as a whole.

Some have viewed with alarm $\mathbb{N}$ est $V$ irginia's population loss, whereas others, though expressing regret, have indicated that under the existing circumstances the State could now take better care of those who remained. Until West Virginin is able to share more intensely in industrial development, as is a lively possibility, population loss is likely to continue.

\footnotetext{
${ }^{2}$ W. W. Armentroul and T. D. Johnson, Types of Farming in Wost Virginfa, West Virgtnla Unlversily Aqriculiural Experiment Station Bulletin 292, Auqust, 1939 , p. 5.

${ }^{1}$ Calculated from successive United States Census data.
} 


\section{POPULATION ESTIMATES FOR JULY 1, 1955}

Table 2 contains the estimates of the July 1, 1955, population for Trest Virginia by counties. These estimates are calculations and not zensus figures. The estimates are derived from the 1950 census, vital statistics, and school enrollment figures by a technique which the Bureau of Census has formulated for small areas-that is, counties, cities, and netropolitan areas.

West Virginia school enrollment figures are generally available for he county units only. Unless other and less reliable techniques would se used, population estimates for small areas other than counties would re possible only as school enrollment figures can be made to correspond o the appropriate geographic units.

\section{:STIMATING PROCEDURES}

The estimates in Table 2 are made by use of the following proceures: ${ }^{4}$

The natural increase figures recorded by the Bureau of Vital Stastics, United States Department of Health, Education, and Welfare, are 'vised for under-registration of births with an adjustment for the perentage of white and non-white in the 1950 population.

The net migration figure is based upon the school enrollment figes for 1955 adjusted by the relationship of the school enrollment of 150 to the age cohort $71 / 4$ to $141 / 4$ and compared with the age cohort $1 / 4$ to $91 / 4$ of the 1950 census adjusted for underenumeration of lower ;e groups and for survival.

This relationship between school enrollment and appropriate age hort is then adjusted so as to he related to the migration of all age oups. The factor 0.94 is the figure which the Bureau of the Census $\mathrm{s}$ discovered to be the one most accurately expressing the relationship tween this particular school enrollment-age cohort and the total popuion.

The 0.91 factor is then multiplied by the 1950 census figures, adsted for underenumeration of younger ages, for births occurring 1950 to 55, and for loss to the arned forces.

The product is the net migration for the specific area concerned. e net loss to the arned forces has heen apportioned to the counties on basis of the county's proportion of 20- to 24-year-old males to the

or a more complete account of the procedures see Unlted States Bureau of the Census, rent Population Reports, Population Esilmatas: Illustrative Example of a Melhod of imating the Current Population of Sub-Divisions of the United Strtes, No. 133. Man-h
1956 , p. 25 . 
State's total of this age group. The estimated population for July 1. 1955 , is the sum of the 1950 civilian population, plus the natural in. crease, (plus or minus) the net migration, less the net loss to the armer forces. Vo adjustment needed to be mnde for increased military personne located within the State since there are no major military installations it Nest Virginia. In considering the accuracy of the estimate of the popu lation for any county, the method used could properly be examined in th light of variations in migration which do not fit the patterns implied i the use of the 0.94 factor between the school encollment-appropriate ag cohort and the total net migration.

\section{SOME REASONS FOR POPULATION CHANGE}

Among the factors in population change which may be used to e: plain the changes in evidence are: (1) a continuing decline in the numb: of persons engaged in agriculture, supplemented by some consióeratic of a better man-land ratio having been achieved in the light of techn logical developments and shifts within agriculture as commercial ente prises; (2) the decline in the number of persons employed in mining, $t$ closing of exhausted mines and the opening of new ones, and the diffe ential advantages of certain mining areas for coal shipments abroad a to industrial areas; (3) the continuing suburban developments which cro county and state boundaries; (4) the beginning of or continuing industri developments.

A field survey is planned for the summer of 1957 to study the " fluence of population change and migration upon rural community li: The field survey is expected to indicate if population gains or loss have continued among a selected list of communities which lost or gain] more than ten per cent between 1940 and 1950. Factors which seem) relate to these population changes will be studied. 